\title{
Farm and Home Technologies for Women Livelihood Promotion - A Case of KVK, Rudrur, Nizamabad, Telangana State
}

\author{
M. Bhavya Manjari ${ }^{*}$, C. Padma Veni ${ }^{2}$ and Venkata Rajkumar ${ }^{3}$ \\ ${ }^{1}$ Department of Home Science, Krishi Vigyan Kendra, Rudrur, Telangana, India \\ ${ }^{2}$ Department of Agricultural Extension, Krishi Vigyan Kendra, Rudrur, Telangana, India \\ ${ }^{3}$ Department of Horticulture, Krishi Vigyan Kendra, Rudrur, Telangana, India \\ *Corresponding author
}

\begin{tabular}{|l|}
\hline Ke y w o r d s \\
Farm and Home \\
$\begin{array}{l}\text { Technologies, } \\
\text { Livelihood Promotion, } \\
\text { Telangana State }\end{array}$ \\
\hline Article Info \\
\hline $\begin{array}{l}\text { Accepted: } \\
\text { 18 September } 2018 \\
\text { Available Online: } \\
\text { 10 October } 2018\end{array}$ \\
\hline \hline
\end{tabular}

A B S T R A C T

Women at Farm and Home contribute to economic growth in developing countries and clearly represent an untapped potential. When women adopt gender sensitive practices they can empower themselves, voice and represent decision making, provide business network, enhance access to market services and facilitate economics of scale. In this connection Krishi Vigyan Kendra, Rudrur conducted On Farm Trials on Farm and Home technologies for women in adopted villages to assess and refine for further demonstration. For wider dissemination of these technologies and for the promotion of livelihood opportunity for the women, the present study was undertaken with the objectives 1 . To Document consolidate feedback of beneficiaries on the results of On Farm Trials (OFT) on Farm and Home technologies as Success Stories for wider dissemination and 2. To propose a strategy for market promotion of Farm and Home technologies as Sustainable women livelihoods. Qualitative feedback was explored and consolidated from the year of inception of the OFT through Focus Group Discussions, frequent Monitoring Visits and Observations. The beneficiaries include 70 Farm and Home women from 9 KVK adopted villages and 40 adolescent girl students of Seed Technology Poly technique College, Rudrur thus totaling to 110. The Farm and Home technologies were obtained from All India Coordinated Research Project, Home Science, Professor Jayashankar Telangana State Agricultural University, Rajendranagar. Extensive village visits with the help of success stories on Farm and Home technologies resulted in identification of interested and needy women and development of strategy for the promotion of women livelihoods by linking to ATMA, Nizamabad under Support to State Extension Programme in Extension Reforms for financial aid and Certified input dealers and Integrated Child Development Services (ICDS), Nizamabad for facilitating marketing opportunity.

\section{Introduction}

Women at Farm and Home contribute to economic growth in developing countries and clearly represent an untapped potential. For many rural women, entrepreneurship is a part of broader livelihood strategy often undertaken partially where it is difficult to separate production and reproduction tasks and market and non- market work. When women adopt gender sensitive practices they can empower themselves, voice and represent 
decision making, provide business network, enhance access to market services and facilitate economics of scale. (FAO, 2010)

Swamy Vivekananda said "Just as a bird could not fly with one wing only, a nation would not march forward if women are left behind". Women population constitute half of the total population i.e. 48.5 percent which indicates potential strength of women in the total human resource in the country. Although women contribute much time and energy to the nation growing their contribution is highly appreciated and scarcely recognized.

Money in the hands of men spend quite differently from money in the hands of women. Cash in the hands of women, often means more nutrition and education for children. Therefore a women controls the household income the family get benefits hence their economic independence is the need of the hour.

The women population in Nizamabad district dominates men with 51 percent, that shows more strength in terms of district human resource but literacy percentage of 52.33 emphasize the need for education and economic empowerment.

In this connection Krishi Vigyan Kendra, Rudrur conducted On Farm Trials on Farm and Home technologies for women in adopted villages to assess and refine for further demonstration so as to promote their livelihood opportunities for sustainable development.

As a technology development process On Farm Trial is conducted for 3 years so as to move through assessment, refinement and demonstration stages and while making modifications some technologies get accepted / rejected at assessment stage while some at refinement and does or does not move to demonstration stage. But the On Farm Trials on Farm and Home technologies conducted by KVK Rudrur got acceptance for adoption while in the assessment and refine stage itself. Hence for wider dissemination of these technologies and to promote livelihood opportunity for the women, the present study was undertaken with the following objectives.

To document consolidate feedback of beneficiaries on the results of the On Farm Trials (OFT) on Farm and Home technologies as success stories for wider dissemination.

To propose a strategy for market promotion of Farm and Home technologies as sustainable women livelihoods.

\section{Materials and Methods}

Qualitative feedback was explored and consolidated from the year of inception of the OFT through focus group discussions, faculty frequent monitoring visits and observations.

The beneficiaries include 70 Farm and Home women from $9 \mathrm{KVK}$ adopted villages and 40 adolescent girl students of Seed Technology Poly technique college, Rudrur thus totaling to 110. The 9 adopted villages comprises Jalalpur, Laxmapur, Sankora from Varni Mandal, Suddulam, Rampur from Kotagiri Mandal and Kistapur, Thimmapur, Mirzapur, Chincholi from Birkur Mandal of Nizamabad District.

The Farm and Home technologies for the On Farm Trials include 1. Rolling brush stem applicator in cotton for the management of sucking pests 2 . Use of Protective clothing while spraying chemicals in the field 3 . Supplementation of Pusthi weaning mix to infants of 6 months to 2 years and 4 . Improvement of hemoglobin through supplementation of Raagi laddu and Drumstick leaf powder among adolescent girls 
which were obtained from All India Coordinated Research Project, Home Science, Professor Jayashankar Telangana State Agricultural University, Rajendranagar.

Extensive village visits were made and motivated women for the use of these technologies with the help of documented success stories.

Identified needy and interested women namely G. Shilpa, Ph.No: 9963698300, Suddulam Village; Smt Shabana, Phone. No: 8886820764, Akbarnagar village; V. Padma, Phone No: 9492649293, Thimmapur village and SHG (Leader Manikyamma), Phone. No: 9989463164, Akbarnagar village to help them to promote their livelihood opportunities on these technologies and linked to Agriculture Technology Management Agency (ATMA), Nizamabad under Support to State Extension Programmes in Extension Reforms.

Further efforts were made, identified and linked women to market Rolling Brushes and Protective Clothes to an elated and enthusiastic input dealers namely Sri. P. Srinivas, Phone No: 9440037925, Balaji Agro Agencies, Kamareddy; Sri. N. Yadagiri, Phone No: 9490806344, Sri Sai Seeds \& Pesticides, Lingampet, Nizamabad; Sri. Kishan, Phone No: 9440525740, Jai Kisan Seeds \& Pesticides, Lingampet, Nizamabad; Sri. Saya Goud, Phone No: 9848913098, Uma Maheshwara Fertilizer, Nagireddypet, Nizamabad presently undergoing a Training Programme on Diploma in Agriculture Extension for Input Dealers (DAESI) 2016-17 at KVK Rudrur who come forward voluntarily to facilitate them for marketing without expecting a single rupee in return.

Similarly linked to Integrated Child Development Services (ICDS), Nizamabad to market Raagi laddu, Drumstick leaf powder and Pushti weaning mix as business facilitators.

\section{Presentation of Success Stories}

\section{Farm Technologies}

\section{Success Story - 1}

\section{Successful on farm trial on rolling brush for stem application in cotton}

Cotton is grown in Nizamabad district as commercial crop, which is attacked by a number of pests out of which sucking pests cause considerable damage in the initial stage and bollworms in the latter stage of the crop growth. For the control of sucking pests, farmers are spraying huge chemical pesticides in more dosage at more intervals and incurring more cost.

With a gender mainstreaming perspective in agriculture men and women farmers need to be focussed and involved equally in all the farming operations. Spraying operation by men farmer involves more drudgery for women farmer to carry as it is. All India Coordinated Research Project (AICRP) FRM department, PG \& RC, PJTSAU, Rajendranagar designed Rolling brush for stem application in cotton for the control of sucking pests as a drudgery reduction technology for both men and women on which KVK, Rudrur conducted On Farm Trail during 2015-16.

Basing the feedback from men and women farmers that, women experienced safe and smooth performance while spraying chemical for the control of sucking pests in cotton and also seeing and observing the benefits as furnished in the table, Krishi Vigyan Kendra, Rudrur believed in the success of the technology and identified Smt. G. Shilpa, the most needy, economically poor and interested farm women to start entrepreneurship on Rolling brush marketing for her livelihood promotion. 
Skill teaching on Use of Rolling brush for stem application for control of sucking pests in Cotton

\section{Success Story -2}

\section{Protective clothing protects from health hazards}

Exposure to chemical pesticides while spraying in their field has become a major health problem for farmers in Telangana state with a special mention to Nizamabad district. Though there is no serious pest attack in the field, the farmer in order to reap riches have been using pesticides extensively and as a result is suffering from various ailments. The death case of Y. Venugopal, 22 year old son of Y. Satyanarayana, Retired Senior Assistant of our own Regional Sugar Cane \& Rice Research Station (RS\&RRS), Rudrur after inhaling the vapor while spraying chemicals Nuvacron + Dithane M 45 + Baviston in his field is pinching to remember even today.

Majority of the farmer suffer from various ailments due to spraying of such pesticides such as nausea, vomiting, headache, skin disorders, digestive problems and breathing problems. They spray chemicals without taking basic safety precautions such as wearing masks and gloves. Many a times they inhale the pesticides while spraying it against the wind direction.

Expressing a concern over farmers, not following minimum safety precautions while spraying pesticides, Krishi Vigyan Kendra, Rudrur conducted On Farm Trial on Protective clothing. Home Scientist, received this technology from Home science, All India Coordinated Research Project (AICRP) Textiles department, Post Graduate \& Research Centre, Rajendranagar. Assessing, and refining of any technology requires three years so as to move to next stage i.e
Demonstration (FLD) but Protective Clothing got acceptance from farmers during assessment stage itself.

Seeing and believing the benefits of protective clothing like as experienced by five farmers namely Gajanand, K. Srinivas Reddy, Sailu, G. Vittal and T. Laxman in all the crops while spraying the chemicals, the neighboring farmers got attracted and gone for protective clothing from Kharif 2016 which includes

This technology proved technologically feasible, economically profitable, ecologically sustainable and culturally compatible with little refinement by the farmers in adding sunglasses.

\section{Home Technologies}

\section{Success Story -3}

\section{Pushti - A Secret of Shakti}

A needy woman once upon a time, owns the small entrepreneurship now for selling Pushti weaning mix earning Rs.5000/- per month.

This is the success story of Smt. K. Padma, mother of infant beneficiary of Pushti weaning mix from Kistapur village, Birkur Mandal, Nizamabad district.

Pushti weaning mix is a supplementary food consisting roasted wheat ravva, roasted soya dal and jaggery with following nutritive values and child health benefits.

The Home Scientist conducted 3 On Farm Trials during 2011-14 in KVK adopted villages which has gone to Front Line Demonstration during 2014-15 that improved the health of the infant child significantly after four months of feeding in terms of gaining body weight of $1.25 \mathrm{kgs}$ compared to child fed with normal weaning mix. 
Table.1 Consolidated feedback of Beneficiaries on the use of Rolling brush for spraying chemical

\begin{tabular}{|c|c|c|c|c|}
\hline \multirow[t]{2}{*}{ S. No } & \multicolumn{3}{|c|}{ Parameters } & \multirow[t]{2}{*}{ Result } \\
\hline & $\begin{array}{l}\text { Time required to } \\
\text { spray chemical and } \\
\text { no. of labour }\end{array}$ & Chemical dosage & $\begin{array}{l}\text { Labour } \\
\text { charges }\end{array}$ & \\
\hline $\begin{array}{l}\text { Rolling Brush } \\
\text { method }\end{array}$ & $\begin{array}{l}\text { Less time (6 hours / } \\
\text { day- one labour- } 3 \\
\text { times in a crop } \\
\text { season }=6 \text { hours X } 1 \\
\text { X } 3=18 \text { hours }\end{array}$ & $\begin{array}{c}250 \mathrm{ml} \\
\text { Monocrotophos/L/ } \\
\text { acre }\end{array}$ & $\begin{array}{l}\text { Rs. } 1500 / \\
\text { acre }\end{array}$ & $\begin{array}{ll}\cdot & \text { Less time } \\
\cdot & \text { Less chemical dosage } \\
\cdot & \text { Less no. of labour } \\
\cdot & \text { Less investment } \\
\cdot & \text { No environment pollution } \\
\dot{\text { killed }} & \text { Only harmful insects getting } \\
\cdot & \text { Physical stress reduction }\end{array}$ \\
\hline $\begin{array}{l}\text { Farmer's } \\
\text { normal } \\
\text { practice of } \\
\text { Spraying }\end{array}$ & $\begin{array}{l}\text { More time ( } 3 \text { hours)- } \\
2 \text { labours- } 5 \text { times in } \\
\text { crop season }=3 \mathrm{~h} \text { X } 2 \\
\quad X 5=30 \text { hours }\end{array}$ & $\begin{array}{l}1 \mathrm{~L} \text { Monocrotophos } \\
\text { /200 L water / acre }\end{array}$ & $\begin{array}{l}\text { Rs. } 2500 / \\
\text { acre }\end{array}$ & $\begin{array}{ll}\text { - } & \text { More time } \\
\text { - } & \text { More chemical dosage } \\
\text { - } & \text { More no. of labour } \\
\text { - } & \text { Environmentment pollution } \\
\text { insects getting killed } & \text { Both beneficial \& harmful }\end{array}$ \\
\hline
\end{tabular}

Table.2 Nutritive values and health benefits of Pushti

\begin{tabular}{|l|l|}
\hline $\begin{array}{l}\text { S. } \\
\text { No }\end{array}$ & $\begin{array}{l}\text { Nutritive values in } \mathbf{1 0 0} \text { gms of } \\
\text { Pushti }\end{array}$ \\
\hline $\mathbf{1}$ & Calories- 363 \\
\hline 2 & Protein $-18.1 \mathrm{~g}$ \\
\hline $\mathbf{3}$ & Iron $-6.3 \mathrm{mg}$ \\
\hline $\mathbf{4}$ & Carotene -136 \\
\hline
\end{tabular}

\begin{tabular}{|l|l|}
\hline $\begin{array}{l}\text { S. } \\
\text { No }\end{array}$ & Child Health benefits \\
\hline 1 & Good physical development \\
\hline 2 & Cognitive development \\
\hline 3 & Psycho motor skill development \\
\hline 4 & Social development \\
\hline
\end{tabular}

Table.3 The economics of preparation of Pushti weaning mix

\begin{tabular}{|c|c|c|c|c|c|c|}
\hline \multicolumn{6}{|c|}{ The economics of Pushti weaning mix } & \multirow{2}{*}{$\begin{array}{l}\text { During 2015-16 } \\
\text { Increased earnings by March, } \\
2016 \text { by selling } 10 \mathrm{kgs}\end{array}$} \\
\hline $\begin{array}{l}\text { Required } \\
\text { Ingredients }\end{array}$ & $\begin{array}{l}\text { Cost per } \\
\mathrm{kg}\end{array}$ & $\begin{array}{l}\text { For } 1 \mathrm{~kg} \\
\text { pushti } \\
\text { preparation } \\
\text { required } \\
\text { quantity }\end{array}$ & $\begin{array}{l}\text { Cost of } \\
\text { each } \\
\text { product } \\
\text { for } 1 \mathrm{~kg} \\
\text { pushti }\end{array}$ & $\begin{array}{l}\text { Invested } \\
\text { Rupees for the } \\
\text { preparation of } \\
5 \mathrm{kgs} \text { pushti }\end{array}$ & $\begin{array}{l}\text { Initial earnings during } \\
\text { March } 2014 \\
\text { With } 5 \mathrm{~kg} \text { Pushti @ } \\
\text { 40/- per } 100 \text { pkt }\end{array}$ & \\
\hline Wheat rava & Rs 55/- & $667 \mathrm{gms}$ & Rs 37/- & Rs. 185/- & \multirow{3}{*}{$\begin{array}{l}-50 \text { pkt } \times 40 /-=\text { Rs. } \\
2000 /- \\
-\quad \text { Packing \& other } \\
\text { charges = Rs.100/- }\end{array}$} & \multirow{3}{*}{$\begin{array}{l}\text { Due to the demand of the product } \\
\text { she has increase the cost of } \\
\text { packet from Rs. } 40 \text { to Rs.60/- } \\
\text { - } 100 \text { pkt x } 60 /-=6000 /- \\
\text { - Rs. } 200 /-\end{array}$} \\
\hline Soya dal & Rs 140/- & $166 \mathrm{gms}$ & Rs 23/- & Rs. 115/- & & \\
\hline Jaggary & Rs 65/- & $167 \mathrm{gms}$ & Rs 11/- & Rs. 55/- & & \\
\hline & Total & & Rs. 71/- & Rs. 355/- & $\begin{array}{l}\text { Gains }=\text { Rs. } 2000- \\
355+100=\text { Rs. } 1545 /-\end{array}$ & $\begin{array}{l}\text { Gains = Rs. } 6000-710+200= \\
5190 /- \\
* \text { with in } 2 \text { yrs she could gain the } \\
\text { difference of Rs. } 3645 /-\end{array}$ \\
\hline
\end{tabular}


Table.4 Nutritive values and health benefits of Raagi laddu

\begin{tabular}{|l|l|}
\hline $\begin{array}{l}\text { S. } \\
\text { No }\end{array}$ & $\begin{array}{l}\text { Nutritive values in one }(33 \\
\text { gm weight }) \text { Raagi laddu }\end{array}$ \\
\hline 1. & Calcium $-57.4 \mathrm{mg}$ \\
\hline 2. & Calories -23.46 \\
\hline 3. & Protein $-1.05 \mathrm{~g}$ \\
\hline 4. & Iron $-1.425 \mathrm{mg}$ \\
\hline 5. & Beta carotene $-7.01 \mu \mathrm{g}$ \\
\hline 6. & Total folic acid $-3.05 \mathrm{mg}$ \\
\hline 7. & Fat $-1.67 \mathrm{gms}$ \\
\hline
\end{tabular}

\begin{tabular}{|c|c|}
\hline S. No & Health benefits \\
\hline 1 & Preventing malnutrition and anemia \\
\hline 2 & Maintaining bone density and health \\
\hline 3 & Prevalence of diabetes \\
\hline 4 & Accelerating wound healing among diabetics \\
\hline 5 & Anti- microbial property \\
\hline$\overline{6}$ & Anti - cancer potential \\
\hline 7 & Preventing ageing \\
\hline 8 & $\begin{array}{l}\text { Reduces "bad" cholestrol, prevents } \\
\text { cardiovascular disease }\end{array}$ \\
\hline
\end{tabular}

Table.5 Nutritive values and health benefits of Drumstick leaf powder

\begin{tabular}{|l|l|}
\hline $\begin{array}{c}\text { S. } \\
\text { No }\end{array}$ & $\begin{array}{l}\text { Nutritive values in } \mathbf{1 0 0} \text { gms of } \\
\text { drumstick leaf powder }\end{array}$ \\
\hline 1. & Calcium $-2,003 \mathrm{mg}$ \\
\hline 2. & Calories- 205 \\
\hline 3. & Protein $-27.1 \mathrm{~g}$ \\
\hline 4. & Iron $-28.2 \mathrm{mg}$ \\
\hline 5. & Vitamin A- $18.9 \mathrm{mg}$ \\
\hline 6. & Vitamin C- $17.3 \mathrm{mg}$ \\
\hline 7. & Riboflavin $(\mathrm{B} 2)-20.5 \mathrm{mg}$ \\
\hline 8. & Carbohydrates- $38.2 \mathrm{~g}$ \\
\hline 9. & Potassium $-1,324 \mathrm{mg}$ \\
\hline
\end{tabular}

\begin{tabular}{|l|l|}
\hline $\begin{array}{l}\text { S. } \\
\text { No }\end{array}$ & Health benefits \\
\hline 1 & Control blood glucose levels \\
\hline 2 & Control blood cholesterol levels \\
\hline 3 & Prevents constipation \\
\hline 4 & Rich in antioxidants \\
\hline 5 & Anti- inflammatory properties \\
\hline 6 & Relieve from menstrual pain \\
\hline 7 & Natural detoxifier \\
\hline 8 & Beneficial for skin, hair and bones \\
\hline 9 & Natural energy booster \\
\hline
\end{tabular}

Table.6 The economics of preparation of Raagi laddu

\begin{tabular}{|c|c|c|c|c|c|c|}
\hline S. No & $\begin{array}{l}\text { Required } \\
\text { Ingredients }\end{array}$ & $\begin{array}{l}\text { Cost } \\
\text { per kg }\end{array}$ & $\begin{array}{l}\text { For } 1 \text { kg } \\
\text { raagi } \\
\text { laddu } \\
\text { preparati } \\
\text { on } \\
\text { required } \\
\text { quantity }\end{array}$ & $\begin{array}{l}\text { Cost of } \\
\text { each } \\
\text { product for } \\
1 \text { kg raagi } \\
\text { laddu }\end{array}$ & $\begin{array}{l}\text { Invested Rupees for the } \\
\text { preparation of } 5 \mathrm{kgs} \\
\text { Raagi laddu }\end{array}$ & $\begin{array}{l}\text { Earnings by } \\
\text { selling } 5 \text { kgs of } \\
\text { Raagi laddu @ } \\
\text { 15/- per laddu } \\
\text { ( } 30 \text { laddu in } 1 \\
\text { Kg - } 150 \text { laddu } \\
\text { in } 5 \text { kg) }\end{array}$ \\
\hline 1. & Raagulu & Rs 35/- & $500 \mathrm{~g}$ & Rs. 17.50/- & Rs. 88/- & \multirow{4}{*}{$\begin{array}{l}\text { Gains }=150 \times 15 \\
/-=2250-503= \\
1747 /-\end{array}$} \\
\hline 2. & Ground nut & Rs 120/- & $125 \mathrm{~g}$ & Rs. 18/- & Rs. 90/- & \\
\hline \multirow[t]{2}{*}{3.} & Jaggary & Rs 65/- & $375 \mathrm{~g}$ & Rs. 25/- & Rs. 125/- & \\
\hline & \multicolumn{3}{|c|}{ Total } & Rs. 61/- & $\begin{array}{c}\text { Rs. 303/- } \\
\text { Making, Packing \& other } \\
\text { charges }=\text { Rs.200/- }\end{array}$ & \\
\hline
\end{tabular}


Table.7 The economics of Preparation of Drumstick leaf powder

\begin{tabular}{|c|c|c|c|}
\hline $\begin{array}{l}\text { S. } \\
\text { No }\end{array}$ & $\begin{array}{l}\text { Required } \\
\text { Ingredients }\end{array}$ & $\begin{array}{l}\text { For } 1 \mathrm{~kg} \text { powder } \\
\text { preparation required } \\
\text { quantity of drumstick leaves }\end{array}$ & $\begin{array}{l}\text { Earnings from March } 2016 \\
\text { With } 1 \text { kg drumstick leaf powder @ 50/- per 50gms } 20 \\
\text { pkts }\end{array}$ \\
\hline 1. & $\begin{array}{l}\text { Drumstick } \\
\text { leaves }\end{array}$ & $10 \mathrm{kgs}$ & $\begin{array}{l}\text { - } 20 \text { pkt x 50/- = Rs. } 1000 /- \\
\text { Packing \& other charges = Rs. } 100 /-\end{array}$ \\
\hline & & Total & Gains $=$ Rs. $1000-100=$ Rs. $900 /-$ \\
\hline
\end{tabular}

Strategy for market promotion of farm and home technologies as

\section{Sustainable women livelihoods}

\begin{tabular}{|c|c|c|c|c|c|c|}
\hline S. No & $\begin{array}{l}\text { Name of the } \\
\text { technology }\end{array}$ & $\begin{array}{l}\text { Name of the } \\
\text { identified women }\end{array}$ & $\begin{array}{l}\text { Details of } \\
\text { strategy }\end{array}$ & $\begin{array}{l}\text { Cost of one } \\
\text { unit }\end{array}$ & Cost of total unit & Expected Income \\
\hline 1. & Rolling brush & $\begin{array}{l}\text { G. Shilpa } \\
\text { W/O G.Gaganan } \\
\text { Suddulam, Village, } \\
\text { Kotagiri } \\
\text { mandal,NZB,Dist } \\
\text { Ph.No: 9963698300 }\end{array}$ & $\begin{array}{l}\text { Imparted } \\
\text { training on } \\
\text { preparation of } \\
\text { Rolling brush } \\
\text { and obtained the } \\
\text { making cost of } \\
\text { rolling brush. }\end{array}$ & $\begin{array}{l}200 \text { Rolling } \\
\text { Brushes @ Rs. } \\
\text { 250/- per brush }\end{array}$ & $50,000.00$ & Rs. $6,000.00$ \\
\hline 2. & $\begin{array}{l}\text { Protective } \\
\text { clothing }\end{array}$ & $\begin{array}{l}\text { Shabana. } \\
\text { Akbar nagar, } \\
\text { Rudrur mandal, } \\
\text { NZB } \\
\text { Phone.No: } \\
\text { 8886820764 }\end{array}$ & $\begin{array}{l}\text { Imparted } \\
\text { training at KVK } \\
\text { Rudrur on the } \\
\text { preparation of } \\
\text { Protective } \\
\text { clothing and } \\
\text { obtained the } \\
\text { cost of making } \\
\text { a set of } \\
\text { protective } \\
\text { clothing }\end{array}$ & $\begin{array}{l}\text { Rs. 500/- } \\
\text { (50 sets) }\end{array}$ & $25,000.00$ & Rs. $5,000.00$ \\
\hline 3. & $\begin{array}{l}\text { Pushti weaning } \\
\text { mix }\end{array}$ & $\begin{array}{l}\text { V. Padma, } \\
\text { Daughter of } \\
\text { Satyanarayana } \\
\text { Thimmapur, } \\
\text { Birkur Mandal } \\
\text { Phone No: } \\
9492649293\end{array}$ & $\begin{array}{l}\text { Imparted } \\
\text { training at her } \\
\text { home on the } \\
\text { preparation of } \\
\text { Pushti weaning } \\
\text { mix and } \\
\text { obtained } \\
\text { making charges } \\
\text { for } 10 \mathrm{~kg} \\
\text { product for } 2 \\
\text { months }\end{array}$ & $\begin{array}{l}500 \\
\text { Pushti } \\
\text { weaning mix } \\
\text { Pkts (100 } \\
\text { grams each) } \\
\text { for two months } \\
\text { business }\end{array}$ & $50,000.00$ & Rs. $5,000.00$ \\
\hline 4. & $\begin{array}{l}\text { Raagi laddu and } \\
\text { drumstick leaf } \\
\text { powder }\end{array}$ & $\begin{array}{l}\text { Manikyamma, } \\
\text { Self Help group } \\
\text { leader, } \\
\text { Akbarnagar } \\
\text { Rudrur mandal, } \\
\text { NZB } \\
\text { Phone.No: } \\
\text { 9989463164 }\end{array}$ & $\begin{array}{l}\text { Imparted } \\
\text { training to SHG } \\
\text { on the } \\
\text { preparation of } \\
\text { Raagi laddu and } \\
\text { drumstick leaf } \\
\text { powder }\end{array}$ & $50,000.00$ & $50,000.00$ & Rs. $5,000.00$ \\
\hline \multicolumn{5}{|c|}{ TOTAL } & Rs. $1,75,000$ & Rs. $21,000.00$ \\
\hline
\end{tabular}



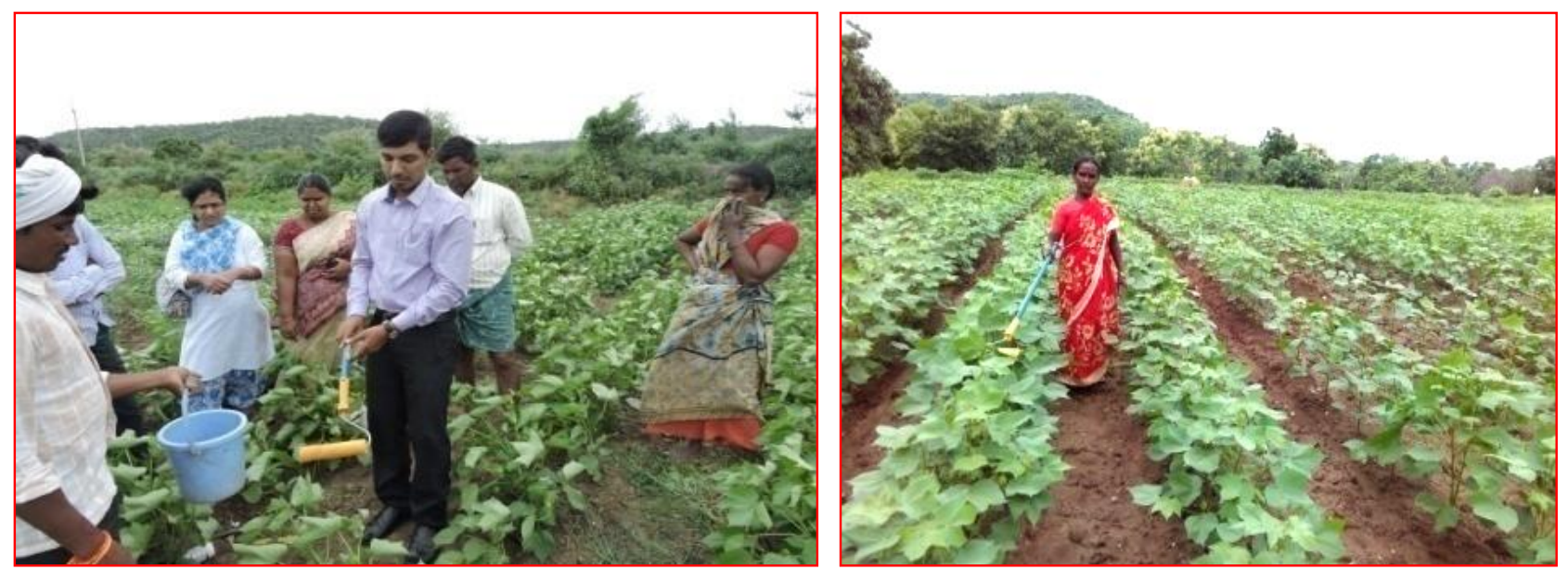

Protective clothing protects from health hazards

\begin{tabular}{|ll|}
\hline - & Getting rid of vomiting $\&$ nausea sensation \\
\hline - & Head ache \\
\hline - & Skin problems \\
\hline
\end{tabular}

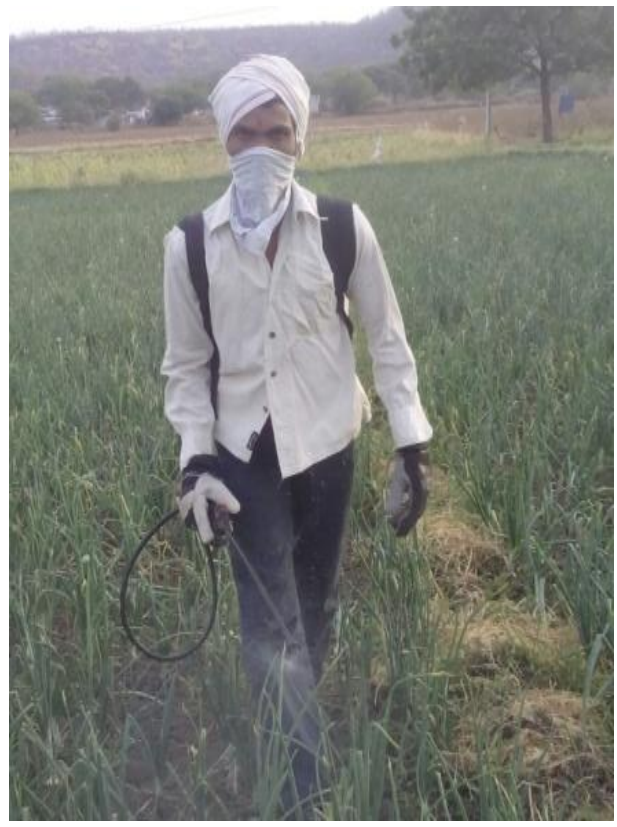

\begin{tabular}{|ll|}
\hline - & Gloves, \\
\hline - & Mask, \\
\hline - & Apron (white cotton shirt) \\
\hline - & Cap \\
\hline
\end{tabular}




\section{Pushti weaning mix}

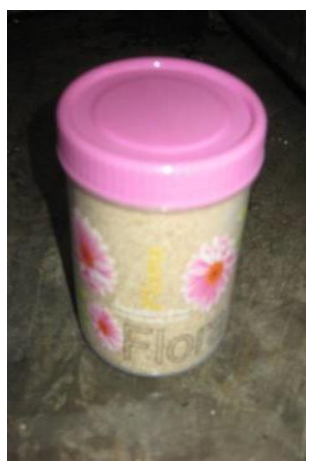

\section{Distributing pushti at Anganwadi center}
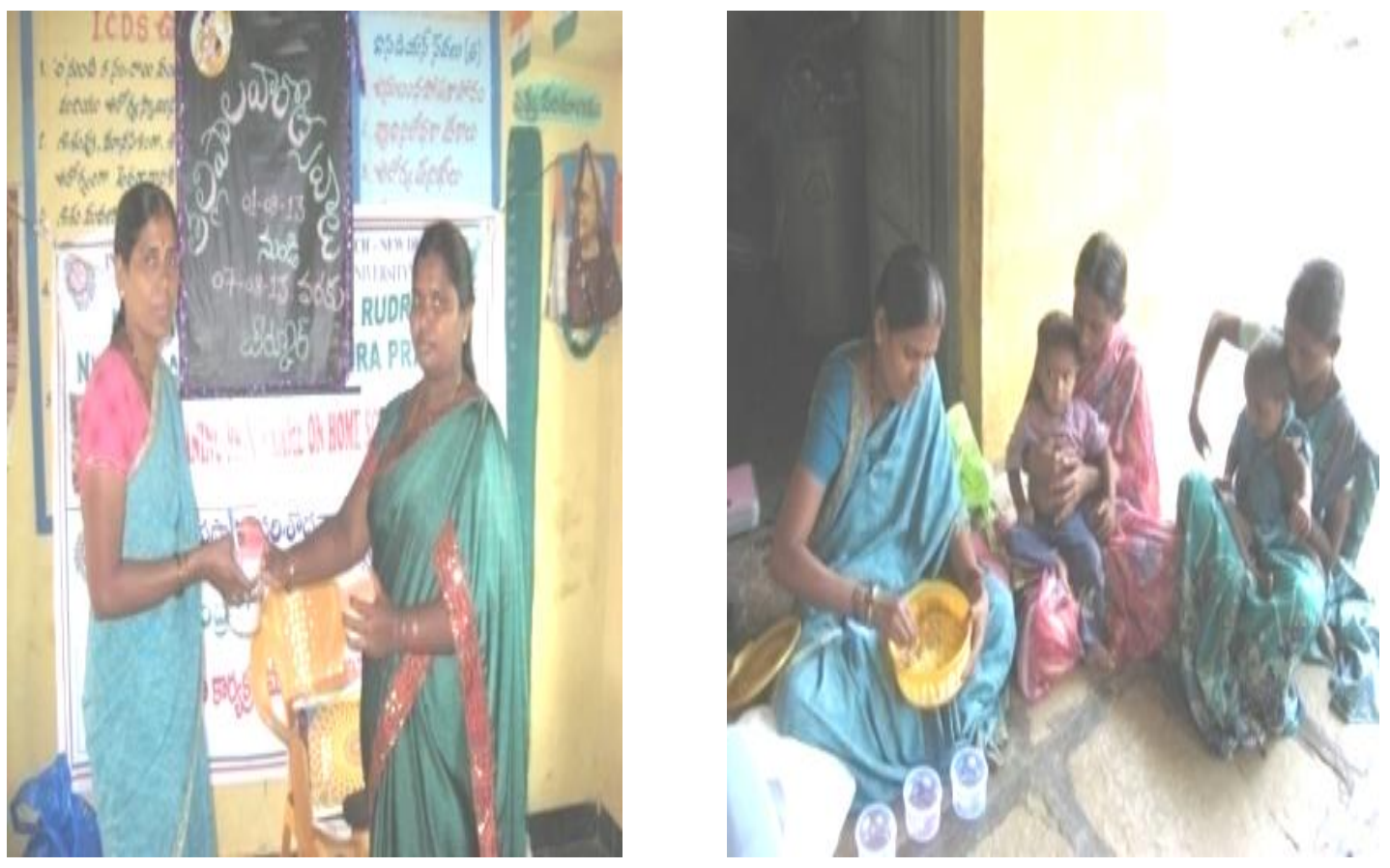

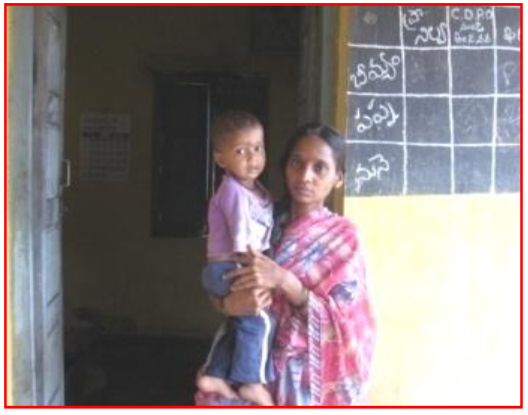

Smt. K. Padma, mother of

Infant beneficiary of Pushti weaning mix

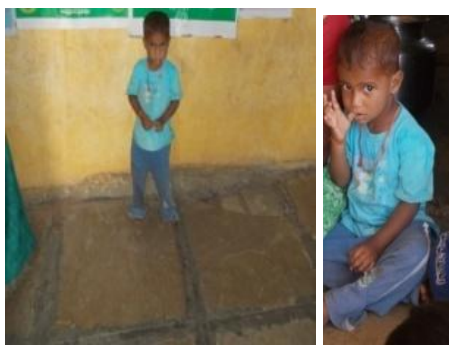

Durga prasad 


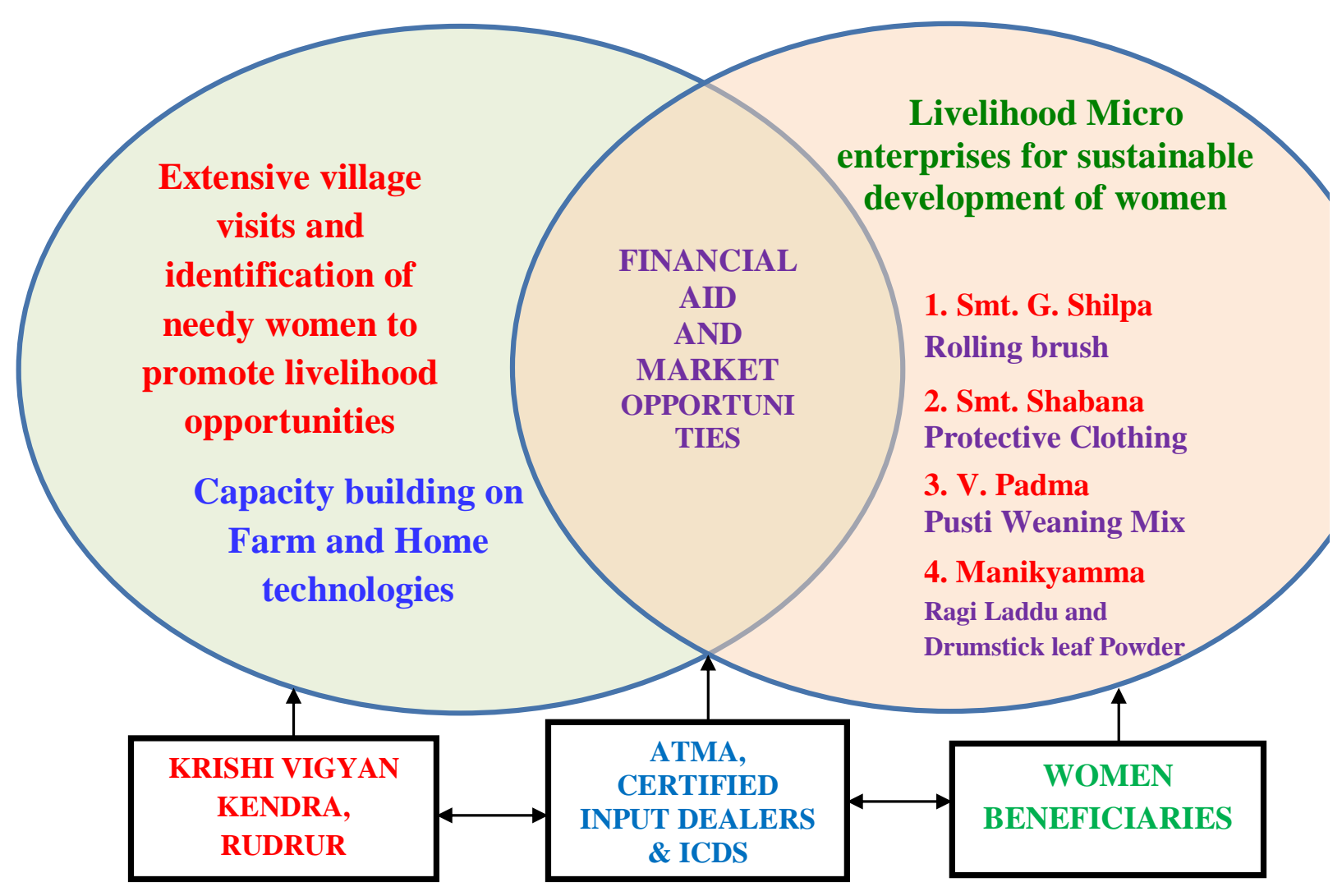

\section{Figure 1. KVK RUDRUR STRATEGY FOR MARKET PROMOTION OF FARM AND HOMETECHNOLOGIES AS SUSTAINABLE WOMEN LIVELIHOODS}

The child health benefits of the Pushti on her own son and other neighbouring infant beneficiaries motivated Padma positively and drove her to start her own selling unit of Pushti at her residence with no extra infrastructure.

Beginning with selling of $5 \mathrm{kgs}$ of Pushti weaning mix in 100gms packet @ 40/- each she has now rose to the occasion to earn income of Rs.5190/- per month by selling 10 $\mathrm{kg}$ pushti and she quotes PUSHTI - $A$ SECRET OF SHAKTI.

As her family is in view of migrating to Maharashtra State, Krishi Vigyan Kendra, Rudrur identified V. Padma to start this entrepreneurship.

\section{Success Story -4}

Raagi Laddu and Drumstick Leaf Powder Empowered Kamala

A passionate mother, Kamala, Rudrur Village who believed the success of On Farm Trial conducted by Home Scientist KVK Rudrur on Improvement of haemoglobin level among adolescent girls through Raagi laddu, Drumstick leaf powder and Iron tablets on her own daughter Supriya, became an entrepreneur by selling Raagi laddu and Drumstick leaf powder earning 2600/- per month.

During 2013-15 the Home Scientist conducted 3 On Farm Trials on Improvement 
of haemoglobin level among adolescent girls through Raagi laddu, Drumstick leaf powder and Iron tablets on STP adolescent girls which has gone to Front Line Demonstration during 2016-17. These trials resulted in improvement of haemoglobin levels and Body Mass Index (BMI) significantly after four months of feeding along with normal diet.

Raagi laddu is supplemented for control of anemia with following nutritive values and health benefits.

Drumstick leaf powder is supplemented for control of anemia with following nutritive values and health benefits.

Kamala, realizing the health benefits started her own enterprise on making and selling of Raagi laddu and drumstick leaf powder earning Rs. 2600/- per month.

"She says this small enterprise economically empowered me to support my family income", while expressing in her inability to continue this business due to personal reasons. Hence, Krishi Vigyan Kendra, Rudrur identified Self Help Group, Akbarnagar to promote this technology.

\section{Strategy for market promotion of farm and home technologies as sustainable women livelihoods}

Programme Coordinator along with Home Scientist extensively visited the villages to motivate Farm and Home women on the above technologies with the help of success stories and identified few interested and needy women to start entrepreneurship by themselves as their livelihood promotion as shown in the below table.

Linked to ATMA under the component of Support to State Extension Programme in Extension Reforms for the financial support for their livelihood promotion for sustainable development.

Further efforts were made, identified and linked women to market Rolling Brushes and Protective Clothes to an elated and enthusiastic input dealers namely Sri. P. Srinivas, Phone No: 9440037925, Balaji Agro Agencies, Kamareddy; Sri. N. Yadagiri, Phone No: 9490806344, Sri Sai Seeds \& Pesticides, Lingampet, Nizamabad; Sri. Kishan, Phone No: 9440525740, Jai Kisan Seeds \& Pesticides, Lingampet, Nizamabad; Sri. Saya Goud, Phone No: 9848913098, Uma Maheshwara Fertilizer, Nagireddypet, Nizamabad presently undergoing a Training Programme on Diploma in Agriculture Extension for Input Dealers (DAESI) 2016-17 at KVK Rudrur who come forward voluntarily to facilitate them for marketing without expecting a single rupee in return. Similarly linked Integrated Child Development Services (ICDS), Nizamabad to women to market Raagi laddu, drumstick leaf powder and Pushti weaning mix as business facilitators.

Building an enabling environment for women's entrepreneurship for livelihood promotion is the need of hour. Given that, the factors limits women entrepreneurship are manifold and intertwined, integrated measures are needed to realize rural women entrepreneurs potential to promote business avenues. In this direction Krishi Vigyan Kendra, Rudrur exerted efforts to disseminate Farm and Home technologies with the use of documented success stories and integrate women livelihood promotion by technological upgradation from the Institution (Krishi Vigyan Kendra, Rudrur) and linking to ATMA, Nizamabad for financial aid and Certified input dealers and ICDS, Nizamabad for market opportunities. The study helped KVK Rudrur to emerge out with a successful model for women livelihood promotion. 


\section{References}

Gender and rural employment policy Brief, 2010. Rural women's entrepreneurship is "good business"! FAO study
Nizamabad district population census, 2011. Population statistics census, 2011.

\section{How to cite this article:}

Bhavya Manjari, M., C. Padma Veni and Venkata Rajkumar. 2018. Farm and Home Technologies for Women Livelihood Promotion - A Case of KVK, Rudrur, Nizamabad, Telangana State. Int.J.Curr.Microbiol.App.Sci. 7(10): 2573-2584.

doi: https://doi.org/10.20546/ijcmas.2018.710.299 